УДК 636.2:619:616.313:631.11(477.53)

(C) 2014

Канівець Н. С., магістр ветеринарної медицини

(науковий керівник - доктор ветеринарних наук, професор П. І. Локес)

Полтавська державна аграрна академія

\title{
ПОШИРЕННЯ ВИРАЗКИ ЯЗИКА У ВЕЛИКОЇ РОГАТОЇ ХУДОБИ У ГОСПОДАРСТВАХ ЦЕНТРАЛЬНОГО РЕГІОНУ УКРАЇНИ
}

\section{Рецензент - кандидат ветеринарних наук I. І. Панікар}

Розглянуто питання поширення виразки язика великої рогатої худоби у господарствах ичентрального регіону України. В результаті огляду продуктів забою встановлено, що в окремих господарствах Полтавської області уражено в середньому 32,6\% тварин. У Котелевському, Решетилівському, Чорнухівському та Шишацькому районах Полтавської області виразка язика реєструється від 15 до $37 \%$ У $У$ районах Сумської, Черкаської та Харківської областей - 17-42\%. Отримані дані свідчать про значне поширення виразки язика великої рогатої худоби у дослідженому регіоні.

Ключові слова: велика рогата худоба, виразка, язик, поширення, захворювання.

Постановка проблеми. Аналіз даних літератури 3 досліджуваної проблеми показує, що погляди як вітчизняних, так і зарубіжних вчених на етіологію виразки язика у великої рогатої худоби доволі суперечливі [4, 6-9]. Існує думка, що захворювання розвивається внаслідок травмування язика твердими частинами грубих кормів. Інші вчені доводять дію інфекційних агентів (у тому числі й мікотичного походження) [6-9]. Крім того, окремі дослідники вказують, що головним фактором виникнення захворювання $є$ аліментарний, зокрема низька поживність кормів і неповноцінність раціону годівлі тварин [4]. Розвиток хвороби залежить від стану обмінних процесів, загальної резистентності, стану здоров'я тварин. Це завдає суттєвих економічних збитків галузі тваринництва [1-3].

Аналіз останніх досліджень i публлікацій, у яких започатковано розв'язання даної проблеми. За даними літературних джерел, виразка язика у великої рогатої худоби є доволі поширеною патологією [6]. Перші згадки про це захворювання в доступній літературі відносяться до початку минулого століття й належать Брейєру (1901) [4]. 3 часом дана проблема знайшла своє відображення у роботах Ніколауса, Ф. Гутіри, I. Марека, V. Capatine, I. Crestea та інших [7, 9]. У сучасній вітчизняній літературі відсутні відо- мості стосовно поширення виразки язика у великої рогатої худоби на території України. Дана публікація $є$ продовженням наших попередніх досліджень із цієї проблеми $[5,6]$.

Мета і завдання досліджень. Метою досліджень стало вивчення поширення виразки язика у великої рогатої худоби в Полтавській області.

Для іiі досягнення головним завданням було проаналізувати результати післязабійного огляду і встановити частку ураження виразкою язика великої рогатої худоби.

Матеріали і методи досліджень. Вивчення поширення патології ми провели, аналізуючи результати забою тварин на м'ясопереробних підприємствах м. Полтава в період 2009-2010 років. Походження тварин встановлювали згідно 3 ветеринарною документацією. Досліджували продукти забою (язики) великої рогатої худоби, які надходили із господарств Котелевського, Полтавського, Решетилівського, Чорнухівського та Шишацького районів Полтавської області.

Визначали загальну кількість тварин із кожного району, кількість уражень язика виразкою та їх частку.

Результати досліджень. Згідно $з$ отриманими на м'ясопереробних підприємствах даними, із господарств Полтавської області надійшло 833 голови великої рогатої худоби. У 400 із них було виявлено виразку язика, що в середньому становить $48 \%$.

Найбільшу частку уражень реєстрували у Полтавському районі - $72 \%$, найменшу - в 3олотоніському - $15 \%$. У Котелевському, Шишацькому і Чорнухівському районах даний показник коливався в межах від 18 до 37 \% (див. рис.). Серед досліджених тварин із господарств Сумської області найменша кількість із патологією язика реєструвалась у Надригалівському районі (19 \%), найбільша - у Сумському (42 \%).

У тварин, які надійшли на забій із господарств Черкаської і Харківської областей, частка виразок язика коливалася в межах від 17 до $19 \%$. 


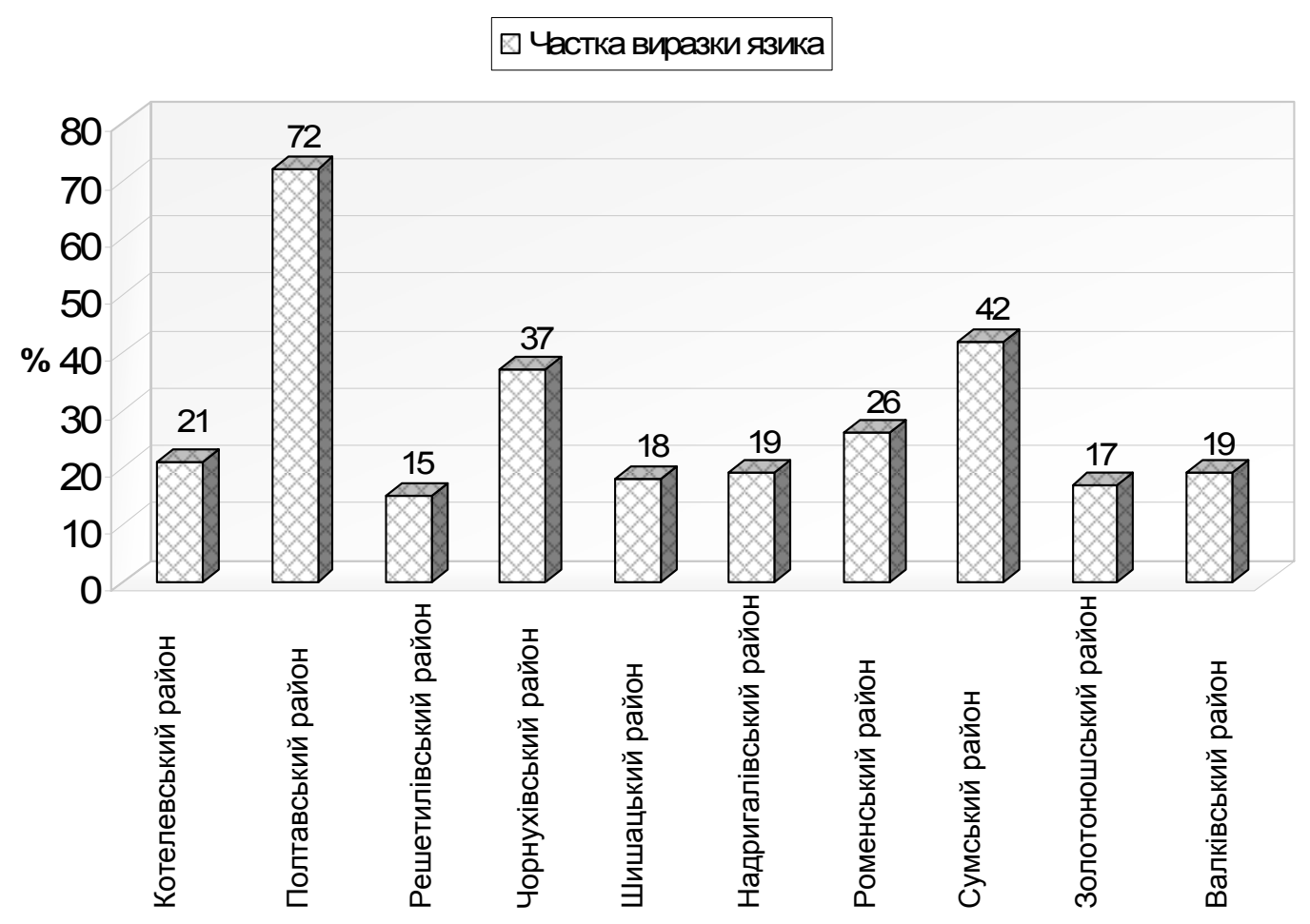

Рис. Діаграма ураження язика великої рогатої худоби виразкою

Аналізуючи результати досліджень продуктів забою тварин можна стверджувати, що кількість виявлених випадків захворювання в межах однієї області коливається від 15 до $72 \%$.

Отримані результати свідчать про те, що виразка язика у великої рогатої худоби є поширеною патологією. Тому перспективою подальших досліджень $є$ всебічне вивчення етіології та па-

\section{БІБЛІОГРАФІЯ}

1. Бородина Н. Б. Проявления в полости рта некоторых заболеваний желудочно-кишечного тракта / Н. Б. Бородина, Г. Д. Куторгин // Консилиум. - 1999. - №3. - С. 50-52.

2. Горлова В. А. Поражения полости рта при системных заболеваниях и нарушениях обменных процессов // Волгоградский стоматологический портал : Студентам [Электронный ресурс] / В. А. Горлова. Режим доступа : http://www.volgostom.ru/referatiterapevticheskayastomatologiya/ porazhenie-polosti-rtapri-sistemnich-zabolevaniyach-i-narushe niyachobmennich-protsessov

3. Дзяд О. В. Патогенетичне обгрунтування корекції метаболічних порушень при ерозивновиразкових ураженнях слизової оболонки порожнини рота : автореф. дис. на здобуття канд. мед. наук : 14.01.22 «Стоматологія» / О. В. Дзяд. - Ін-т стоматології АМН України, тогенезу цього захворювання.

Висновок. За результатами проведених досліджень на м'ясопереробних підприємствах м. Полтава встановлено, що виразка язика у великої рогатої худоби широко розповсюджена в центральному регіоні України й, у тім числі, в Полтавському районі Полтавської області.

2002. $-18 \mathrm{c}$.

4. Свитайло В. А. Иммунологический и биохимический статус у крупного рогатого скота при язвах языка : автореф. дис. на соиск. уч. степ. канд. вет. наук : спец. 16.00.03 «Ветеринарная микробиология, вирусология, микология с микотоксикологией и иммунологией», 16.00 .05 «Ветеринарная хирургия» / В.А.Свитайло. Курск, 2006. - 16 с.

5. Ульянко Н. С. Поширення виразкової хвороби язика великої рогатої худоби у віковому аспекті в господарствах Полтавського району Полтавської області / Н. С. Ульянко // Підсумки наук.-дослід. роботи технологічних ф-тів за 2009 рік : наук.-практ. матеріали конф. проф.-виклад. складу. - Полтава, 2010. С. 99-100.

6. Ульянко Н. С. До питання патогенезу виразкової хвороби язика у великої рогатої худоби / 
Н. С. Ульянко // Вісник Полтавської державної аграрної академії. - 2010. - №2. - С. 195-196.

7. Enzootic ulcer in the back of the tongue in cattle after ingestion of hay containing flower clusters of yellow bristle-grass / E. Fava, F. Rossi, G. Speranzini [et.al.] // Dtsch. Tierarztl. Wochenschr. - 2000. - 107 (9). - P. 351-354.
8. Gill D. R. Tongue Lesions: incidence and effects on performance of feedlot cattle / D. R. Gill, R. G. Panciera, R. A. Smith // Animal Science Research Report. - 1996. - P. 207-210.

9. Isolation of viral agents fromcattle with chronic ulcerative glossitis / C. F. Flammini, S. Cavirani, G. Allergi, L. Zanichelli // Atti Soc. Ital. Buiatria. - 1985. - №17. - P. 597-607. 